\title{
The Pattern of Glomerular Map Formation Defines Responsiveness to Aversive Odorants in Mice
}

\author{
Jin Hyung Cho, ${ }^{1,2}$ Janet E. A. Prince, ${ }^{1,2}$ Tyler Cutforth, ${ }^{3}$ and Jean-François Cloutier ${ }^{1,2}$ \\ ${ }^{1}$ Centre for Neuronal Survival, Montreal Neurological Institute, and 2Department of Neurology and Neurosurgery, McGill University, Montréal, Québec, \\ Canada H3A 2B4, and 3Department of Molecular, Cellular, and Developmental Biology, University of California Santa Cruz, Santa Cruz, California 95064
}

In many species, the detection and recognition of odors is critical to regulate behaviors that are essential for survival, such as foraging for food and avoidance of predators. The formation of complex stereotypic connections between olfactory sensory neurons (OSNs) and second-order neurons in the olfactory bulb $(\mathrm{OB})$ is believed to be important for accurate odorant information processing. In mice, ablation of OSNs that innervate the dorsal region of the OB leads to a loss of avoidance behavior in response to aversive and predator odorants (Kobayakawa et al., 2007). It remains to be determined whether the accurate formation of a glomerular map in this region of the $\mathrm{OB}$ is required for these innate responses. Here, we have generated mice that lack expression of the axon guidance receptor Robo- 2 in OSNs and found that ablation of Robo-2 expression leads to mistargeting of subsets of OSN axons within the dorsal region of the OB. Furthermore, these mice show decreased avoidance behavior toward the predator odorant trimethyl-thiazoline. Our results indicate that the pattern of glomerular innervation in the $\mathrm{OB}$ is critical for innate behavioral responses in mice.

\section{Introduction}

Odor recognition is mediated by olfactory sensory neurons (OSNs) located in the olfactory epithelium (OE). OSNs project their axons to the olfactory bulb (OB), where they make synaptic connections with second-order neurons in neuropil structures termed glomeruli (Mombaerts, 2006). Odorants are detected by olfactory receptors (ORs) expressed on OSNs (Buck and Axel, 1991; Zhao et al., 1998). Each OSN expresses a single type of OR, and axons of OSNs expressing the same OR coalesce into stereotypically conserved glomeruli (Ressler et al., 1994; Vassar et al., 1994; Mombaerts et al., 1996; Malnic et al., 1999; Serizawa et al., 2003). The formation of the glomerular map is dependent on the expression of ORs, adhesion molecules, and axon guidance cues by OSNs (for review, see Mombaerts, 2006; Cho et al., 2009), (Imai et al., 2009; Tsuboi et al., 2009; Takahashi et al., 2010; Takeuchi et al. 2010). The spatial arrangement of glomeruli within the $\mathrm{OB}$ is believed to contribute to the coding of odor information (Mori et al., 2006; Johnson and Leon, 2007).

The dorsal OB receives input from OSNs located in the dorsomedial region of the OE that express either class I or class II

Received May 12, 2010; revised March 9, 2011; accepted April 15, 2011.

Author contributions: J.H.C. and J.-F.C. designed research; J.H.C. and J.E.A.P. performed research; T.C. contributed unpublished reagents/analytic tools; J.H.C., J.E.A.P., and J.-F.C. analyzed data; J.-F.C. wrote the paper.

This work was supported by the Canadian Institutes for Health Research, the Fonds Québécois pour la Recherche sur la Nature et les Technologies, and the Canada Foundation for Innovation. J.H.C. holds a studentship from the Fonds de Recherche en Santé du Québec. J.E.A. Prince held a Master's studentship from the Natural Sciences and Engineering Research Council of Canada and holds a Ph.D. studentship from the Fonds Québécois pour la Recherche sur la Nature et les Technologies. J.-F.C. holds a Canada Research Chair in developmental neurobiology. We thank Bill Andrews and John Parnavelas for providing us with the Robo-2 mouse line and Thomas Bozza for the S50-tau-GFP and M72-tau-lacZ mouse lines. We also thank Don Van Meyel for comments on the manuscript and Armen Saghatelyan for discussions on olfactory behavior tests.

Correspondence should be addressed to Jean-François Cloutier at the above addresses. E-mail: jf.cloutier@ mcgill.ca.

DOI:10.1523/JNEUROSCI.2460-10.2011

Copyright $\odot 2011$ the authors $\quad 0270-6474 / 11 / 317920-07 \$ 15.00 / 0$ odorant receptors. Class I and class II ORs are phylogenetically distinct, and their glomeruli are segregated into the DI and DII regions of the dorsal OB, respectively (Fig. 1A) (Zhang et al., 2004; Miyamichi et al., 2005; Tsuboi et al., 2006; Kobayakawa et al., 2007; Bozza et al., 2009). Activation of glomeruli in these two regions has been linked to innate avoidance responses to aversive odors, such as those emanating from spoiled food and predator urine (Kobayakawa et al., 2007). Mitral cells are projection neurons that receive inputs from OSNs, and the majority of mitral cells located in the dorsal region of the OB innervate the cortical amygdala, suggesting that it could process olfactory information that elicits innate behaviors (Miyamichi et al., 2011).

Here, we have examined whether formation of an accurate glomerular map is required for responsiveness to aversive cues. Our results indicate that the pattern of glomerular innervation in the DII region of the dorsal OB is critical for avoidance of predator odorants in mice.

\section{Materials and Methods}

Animals. Embryonic day 18 (E18) mouse embryos were obtained from timed pregnant females purchased from Charles River. The following mouse strains have been described previously: floxed robo- 2 mutant $(\mathrm{Lu}$ et al., 2007), OMP-Cre (Eggan et al., 2004), S50-tau-GFP (Bozza et al., 2009), and M72-tau-lacZ (Zheng et al., 2000). MOR1-3-ires-tau-lacZ and MOR174-9-ires-GFP mice were generated by standard homologous recombination methods using the self-excising ACN cassette to remove the neo marker during germline transmission in male chimeras (Bunting et al., 1999). For all analyses performed, robo- $2^{+/+}$; $O M P-C r e$ and robo-2 $2^{+/ l o x}$; OMP-Cre mice were used as controls and compared to robo-2 $2^{\text {lox } / l o x}$; OMP-Cre mice.

Fluorescence in situ hybridization. Nonradioactive, digoxigenin (DIG)labeled or fluorescein-labeled cRNA probes were synthesized from cDNA clones encoding robo-2 (Brose et al., 1999), MOR1-3, or MOR174-9. The coding sequences of MOR1-3 and MOR174-9 were PCR amplified from C57BL/6 genomic DNA using the following oligo- 
A
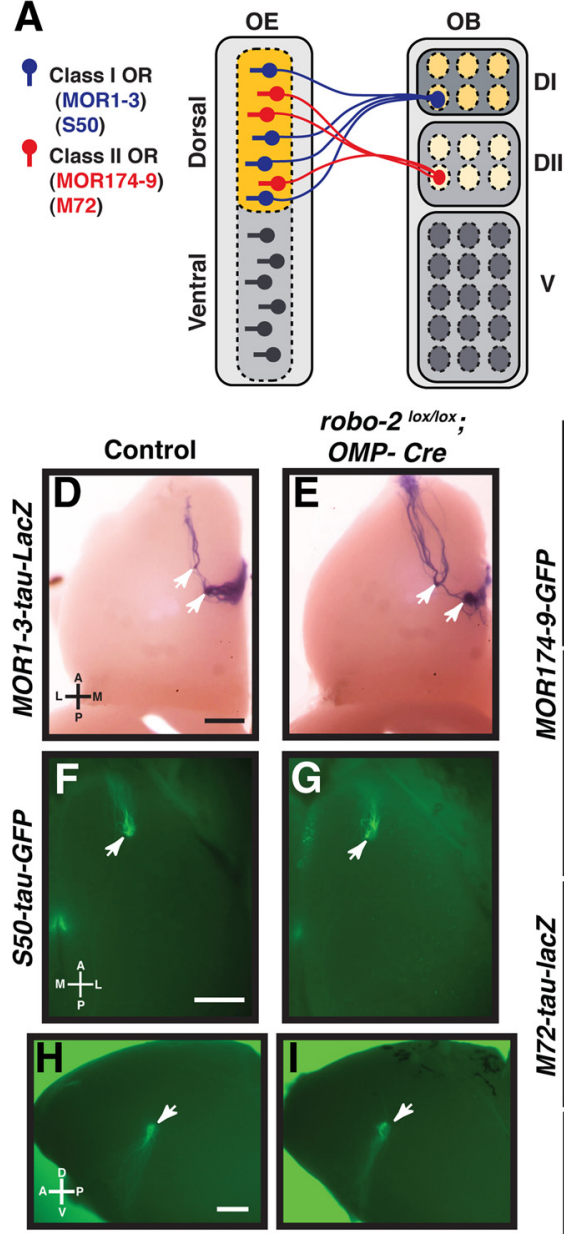
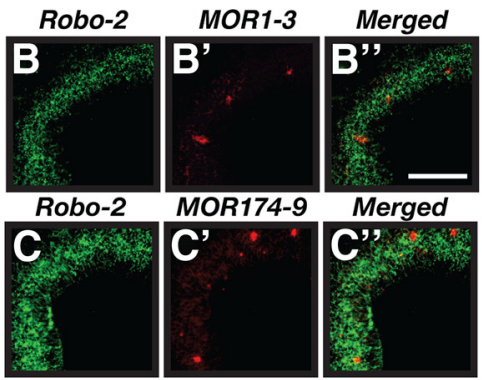

Control
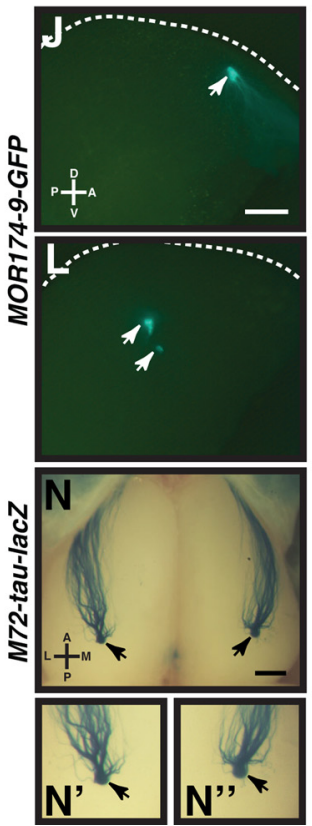

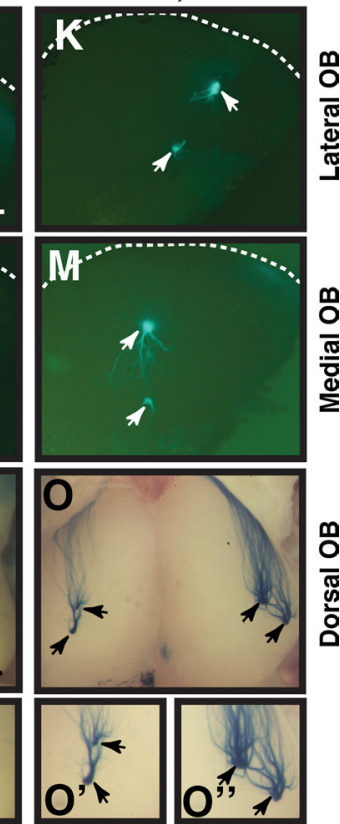

robo-2 lox/lox;OMP-Cre

Figure 1. Robo-2 is expressed in OSNs innervating the dorsal region of the olfactory bulb and is required for the targeting of axons from subsets of OSNs. A, Schematic representation of the pattern of innervation of the olfactory bulb by OSNs. OSNs located in the dorsal region of the 0 E innervate the dorsal part of the $0 B$. In the dorsal OE, OSNs expressing class I ORs, such as MOR1-3 or S50, send their axons to the DI region of the OB, while OSNs expressing class II ORs, such as MOR174-9 or M72, innervate the DII region of the $0 B . B, C$, Fluorescent in situ hybridization of coronal sections of olfactory epithelium isolated from E18 embryos with CRNA probes specific for robo-2 $\left(\boldsymbol{B}, \boldsymbol{B}^{\prime \prime}, \boldsymbol{C}^{\prime} \boldsymbol{C}^{\prime \prime}\right)$, MOR1-3 $\left(\boldsymbol{B}^{\prime}, \boldsymbol{B}^{\prime \prime}\right)$, and MOR174-9 $\left(\boldsymbol{C}^{\prime}, \boldsymbol{C}^{\prime \prime}\right)$. OSNs expressing the class I OR, MOR1-3, or the class II OR, MOR174-9, are located in the dorsomedial region of the OE and express robo-2. Scale bar, $100 \mu \mathrm{m}$. D-I, Whole-mount X-gal-stained or fluorescent views of MOR1-3-expressing $(\boldsymbol{D}, \boldsymbol{E})$ and S50-expressing $(\boldsymbol{F}-\boldsymbol{I})$ OSN projections in adult control $(\boldsymbol{D}, \boldsymbol{F}, \boldsymbol{H})$ and robo-2 $2^{\text {lox/lox}} ;$ OMP-Cre $(\boldsymbol{E}, \boldsymbol{G}, \boldsymbol{I})$ mice. MOR1-3-expressing OSN axons target to one or two glomeruli in the most dorsal region of the $O B(\boldsymbol{D}, \boldsymbol{E})$ (arrowheads). S50-expressing axons innervate glomeruli in the dorsal $(\boldsymbol{F}, \boldsymbol{G})$ and medial $(\boldsymbol{H}, \boldsymbol{I})$ regions

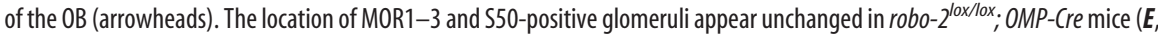
$\mathbf{G}, I) . n=4$ controls and 4 robo-2 $2^{l o x / l o x} ; O M P$-Cre. Scale bars, $500 \mu \mathrm{m}$. D, Dorsal; $\mathrm{V}$, ventral; L, lateral; M, medial. J-O, Whole-mount X-gal-stained or fluorescent views of MOR174-9- $(\boldsymbol{J}-\mathbf{M})$ or M72- $(\boldsymbol{N}, \mathbf{0})$ expressing 0 SN projections in adult control $(\boldsymbol{J}, \mathbf{L}, \mathbf{N})$ and robo-2 $2^{\text {lox/lox }}$ OMP-Cre $(\boldsymbol{K}, \boldsymbol{M}, \mathbf{0})$ mice. MOR174-9-expressing OSN axons innervate one or two glomeruli on the lateral $(\boldsymbol{J}, \boldsymbol{K})$ and medial $(\boldsymbol{L}, \boldsymbol{M})$ sides of the $\mathrm{OB}$ (arrowheads). The location of some of these glomeruli appears shifted toward the ventral part of the OB in most robo-2 $2^{\text {lox/lox}}$; OMP-Cre mice analyzed when compared to controls. M72-expressing OSN axons innervate one glomerulus on the dorsal $(\boldsymbol{N})$ and medial (not shown) regions of the OB (arrowheads). In robo-2 $2^{\text {lox/ox; }}$ OMP-Cre mice, two glomeruli are consistently observed in the dorsal region of the OB (0). High-magnification views of M72-positive glomeruli are shown in $\boldsymbol{N}^{\prime}, \boldsymbol{N}^{\prime \prime}$, $\mathbf{O}^{\prime}$, and $\boldsymbol{O}^{\prime \prime} . n=5$ control; MOR174-9-GFP, 3 control; M72-tau-lacZ, 5 robo-2 ${ }^{\text {lox/lox }}$; OMP-Cre; MOR174-9-GFP, and 3 robo- $2^{\text {lox/lox; }}$; OMP-Cre; M72-tau-lacZ mice. The dorsal limit of the OB is indicated by a white dashed line in J-M. Scale bars, $500 \mu \mathrm{m}$. D, Dorsal; $\mathrm{V}$, ventral; L, lateral; $\mathrm{M}$, medial.

nucleotides: MOR1-3, 5'-TCCTACTGACGGGCTTTCTG-3' and 5' -CATGCTTTCCAAACCT-GTGA-3'; MOR174-9, 5'-AGATGGAAATCACAGTGGGG-3' ${ }^{\prime}$ and $5^{\prime}$-CACAG-AGGCCACTTTTACGG-3'. Sections of OE were processed as described previously (Schaefer et al., 2001; Ishii et al., 2004; Prince et al., 2009).

Analysis of the position of OR-positive glomeruli in adult olfactory bulbs. Adult mice (3 months old) were anesthetized and perfused transcardially with ice-cold PBS containing 4\% paraformaldehyde. Brains were processed as described previously and all sections were collected on microscope slides over the complete rostrocaudal axis of the OB (Cho et al.,
2007). Sections were immunostained with NQO-1 antibodies (1:100; Abcam), and GFP (1:250; Invitrogen) or $\beta$-gal (1:250; MP Biomedicals) antibodies, and counterstained with Hoechst. The position of GFP- or $\beta$-galpositive glomeruli in the $\mathrm{OB}$ was determined using an NIH ImageJ plug-in as previously described (Schaefer et al., 2001). Briefly, images of sections containing GFP- or $\beta$-gal-positive glomeruli were imported into Adobe Photoshop software (Adobe Systems) for mapping of glomeruli. The radial angle of each GFP- or $\beta$-gal-positive glomerulus was measured after setting the origin for each section. The origin was set at one-third the distance between the mitral cell layer in the dorsal region of the $\mathrm{OB}$ and the mitral cell layer in the ventral region of the OB. A scatter plot was constructed that shows the location of GFP- or $\beta$-gal-positive glomeruli in all OBs analyzed in the dorsoventral axis with degrees (radial angle) on the $y$-axis. The mean radial angle for each identified glomerulus was measured and compared between control and robo-2 $2^{\text {lox } / l o x}$;OMP-Cre mice using an unpaired $t$ test.

Immunohistochemical procedures. E13 and E14 mouse embryos or $\mathrm{P} 0$ mouse heads were fixed in $4 \%$ paraformaldehyde for $12 \mathrm{~h}$ and cryoprotected in PBS containing 30\% sucrose. Sections $(20 \mu \mathrm{m})$ were incubated with anti-OMP (1:1000) (Wako Chemicals), anti-Robo-2 (1:350), anti- $\beta$ gal (1: $250)$, or anti- $\beta$ III tubulin (1:1000) (Promega). After rinsing in TBS, sections were incubated with the appropriate Alexa-488- or Alexa-546-conjugated secondary antibody (1:500; Invitrogen).

$X$-Gal staining. For whole-mount X-Gal staining, 3-month-old adult mice were perfused transcardially with ice-cold PBS containing 4\% paraformaldehyde, $2 \mathrm{~mm} \mathrm{MgSO}_{4}$, and 5 mM EGTA. Whole olfactory bulbs were washed twice for $15 \mathrm{~min}$ in $0.1 \mathrm{M}$ phosphate buffer containing $2 \mathrm{~mm}$ magnesium sulfate, $0.01 \%$ sodium deoxycholate, and $0.02 \%$ Nonidet P40 and processed for X-Gal staining. Samples were incubated in $0.1 \mathrm{~m}$ phosphate buffer containing $2 \mathrm{~mm}$ magnesium sulfate, $0.01 \%$ sodium deoxycholate, and $0.02 \%$ Nonidet $\mathrm{P} 40,5 \mathrm{~mm} \mathrm{~K}_{3} \mathrm{Fe}(\mathrm{CN})_{6}, 5 \mathrm{~mm}$ $\mathrm{K}_{4} \mathrm{Fe}(\mathrm{CN})_{6}$, and $1 \mathrm{mg} / \mathrm{ml} \mathrm{X-Gal} \mathrm{for} 1 \mathrm{~h}$ to overnight at $37^{\circ} \mathrm{C}$.

Innate olfactory preference and avoidance tests. For these tests, we followed the published method with slight modifications (Kobayakawa et al., 2007). Three-month-old male robo-2 $2^{\text {lox/lox }}$; OMP-Cre and control littermates were used only once in each test. Individual mice were habituated to the experimental environment for $30 \mathrm{~min}$ and then to the test cage $(30 \times 18 \times 13 \mathrm{~cm})$ for an additional $10 \mathrm{~min}$. After the habituation period, a filter paper $(2 \times$

$2 \mathrm{~cm}$ ) scented with water was introduced and the time each mouse spent investigating the filter paper during a $3 \mathrm{~min}$ test period was measured. The filter paper was taken out and, after a 10 min waiting period, replaced with one scented with test odorant. The investigation time for the odorant-scented filter paper was measured for 3 min.

For the innate olfactory avoidance test, the test cage was visually separated into two areas (1:3) using masking tape on the outside of the cage to discern the two areas during analysis. After habituation, a filter paper $(2 \times 2 \mathrm{~cm})$ scented with water was introduced in the part of the cage 
containing the smaller region and the duration of time spent by the mouse in the larger part of the cage measured over a $3 \mathrm{~min}$ test period. The filter paper was taken out, replaced with a filter paper scented with test odorant and the duration of time spent by the mouse in the large region of the cage was measured. The time spent in the large compartment with the water control was subtracted from the value obtained with odorants to give the recorded avoidance time. Mouse behavior was recorded with a digital video camera for analysis. Odorants used for these analyses were as follows: trimethylthiazoline (TMT) (7.65 M) (Phero Tech), 2-methylbutyric acid (2MB) (8.7 M) (Sigma), and peanut butter $(10 \% \mathrm{w} / \mathrm{v})$. Statistical analyses were performed using unpaired $t$ tests.

Aversion conditioning with $\mathrm{LiCl}$ was adapted from a published procedure (Kobayakawa et al., 2007). robo-2 $2^{l o x / l o x}$; OMP-Cre mice were exposed to TMT $(7.65 \mathrm{M})$ for $3 \mathrm{~min}$ and their avoidance times calculated as described above. For aversive conditioning, $0.5 \mathrm{M} \mathrm{LiCl}$ solution was immediately injected $\left(20 \mathrm{ml} \cdot \mathrm{kg}^{-1}\right)$ into the peritoneal cavity after testing. Two days later, the mice were subjected to the olfactory avoidance test with TMT, and avoidance times were measured. A paired $t$ test was performed for statistical analysis.

\section{Results}

Robo- 2 is required for the targeting of MOR174-9 and M72 OSN axons in the OB

We have previously shown that the axon guidance receptor Robo-2 is highly expressed in OSNs located in the dorsomedial region of the OE, and that Robo- 2 is required to prevent dorsally projecting OSN axons from inappropriately innervating the ventral region of the $\mathrm{OB}$ (Cho et al., 2007). In situ hybridization analyses revealed that OSNs located in the dorsomedial region of the $\mathrm{OB}$ expressing either class I or class II ORs express high levels of robo-2 (Fig. $1 B-B^{\prime \prime}, C-C^{\prime \prime}$ ). To address whether Robo-2 is required for the accurate coalescence of OSN axons into specific glomeruli, we ablated expression of Robo-2 in OSNs and examined the projections of subpopulations of OSNs that send their axons to the DI and DII regions of the dorsal OB. These subpopulations of OSNs express either of the class I ORs, MOR1-3 and S50, or the class II ORs MOR174-9 and M72.

To ablate expression of Robo-2 in OSNs, we generated robo- 2 conditional mice expressing Cre recombinase under the control of the olfactory marker protein $(O M P)$ promoter. In these mice, Robo- 2 expression is ablated in axons of OSNs by E14 but not in cells of the $\mathrm{OB}$ (Fig. $2 A-P$ ). Importantly, we found no additional Cre-induced recombination in any brain structures of the same OMP-Cre mouse (supplemental Fig. S1, available at www.jneurosci.org as supple-
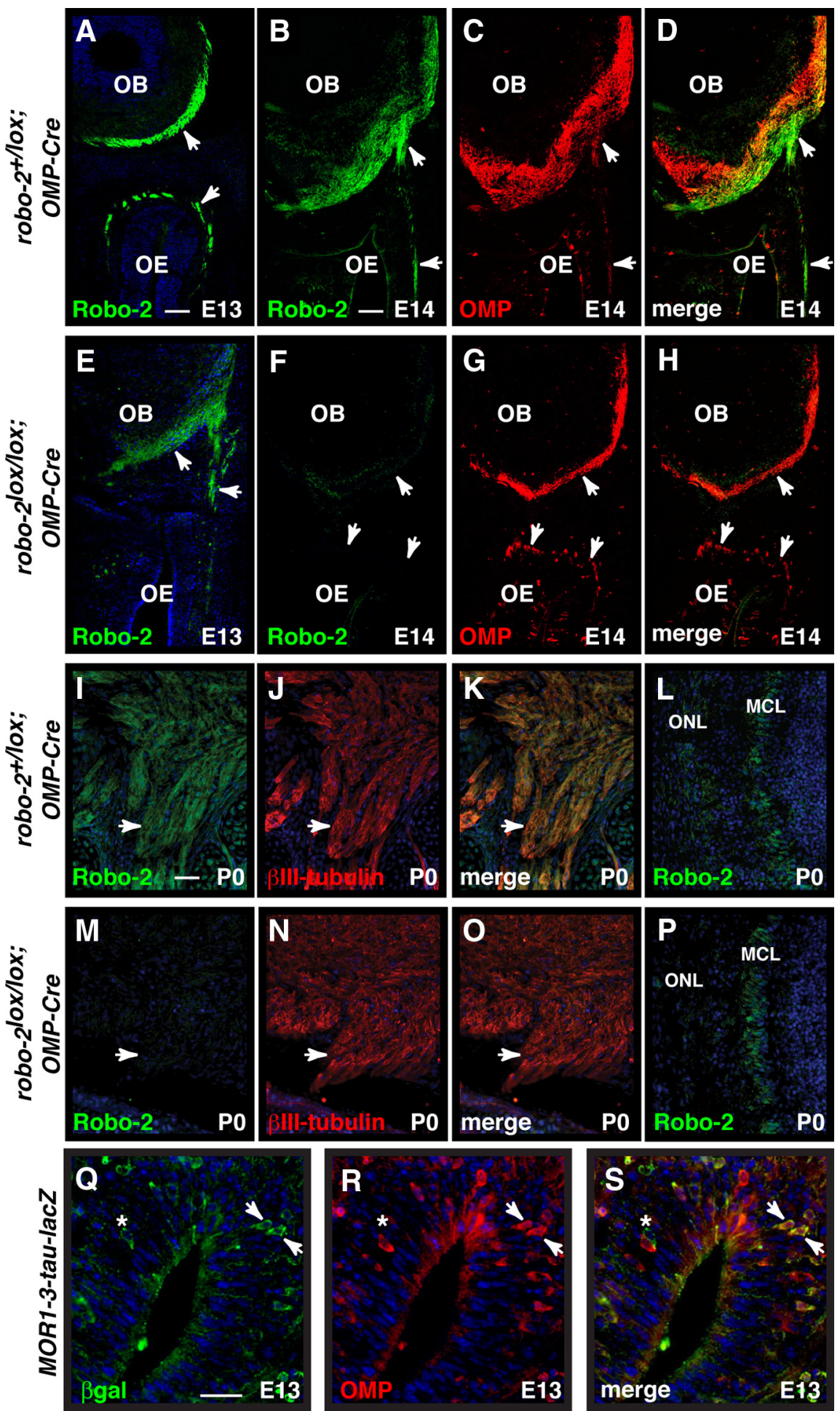

Figure 2. Ablation of Robo-2 expression in $0 S N$ axons. $A-P$, Coronal sections of $O B$ s from E13, E14, and $P 0$ robo-2 $2^{+/ l o x} ; O M P$-Cre $(\boldsymbol{A}-\boldsymbol{D}, \boldsymbol{I}-\boldsymbol{L})$ or robo-2 $2^{\text {lox/lox}} ;$ OMP-Cre $(\boldsymbol{E}-\boldsymbol{H}, \boldsymbol{M}-\boldsymbol{P})$ embryos stained with Robo-2 $(\boldsymbol{A}, \boldsymbol{B}, \boldsymbol{D}, \boldsymbol{E}, \boldsymbol{F}, \boldsymbol{H}, \boldsymbol{I}, \boldsymbol{K}, \boldsymbol{L}, \boldsymbol{M}, \mathbf{O}, \boldsymbol{P}), \mathrm{OMP}(\boldsymbol{C}, \boldsymbol{D}, \boldsymbol{G}, \boldsymbol{H})$, or $\beta$-III tubulin antibodies $(\boldsymbol{J}, \boldsymbol{K}, \boldsymbol{N}, \mathbf{O})$. The Robo-2 expression observed on OSN axons (arrowheads) in robo-2 ${ }^{+/ l o x} ;$ OMP-Cre mice $(\boldsymbol{A}, \boldsymbol{B}, \boldsymbol{I})$ is diminished at E13 $(\boldsymbol{E})$ and ablated at E14 $(\boldsymbol{F})$ and P0 $(\boldsymbol{M})$ in robo-2 $2^{\text {lox/lox}} ;$ OMP-Cre mice. In contrast, Robo-2 is still expressed in the mitral cell layer of the $0 B$ in robo-2 $2^{\text {lox/lox}} ;$ OMP-Cre mice $(\boldsymbol{P})$. MCL, Mitral cell layer; ONL, olfactory nerve layer. Scale bars: $\boldsymbol{A}-\boldsymbol{H}, 125 \mu \mathrm{m} ; \boldsymbol{I}-\boldsymbol{P}, 50 \mu \mathrm{m}$. $\mathbf{Q}-\mathbf{S}$, Coronal sections of 0 E from E13 MOR1-3-tau-lacZ embryos stained with $\beta$-gal $(\mathbf{Q}, \mathbf{S})$ and $\operatorname{OMP}(\boldsymbol{R}, \boldsymbol{S})$ antibodies. While the majority of MOR1-3-expressing cells also express OMP (arrowheads) at that stage of development, some MOR1-3-positive cells do not express OMP (asterisk). The late onset of OMP expression in a portion of dorsal OSNs may

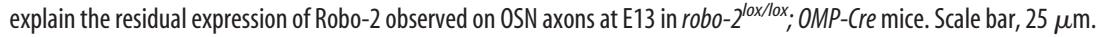




\section{Dorsolateral glomerulus}

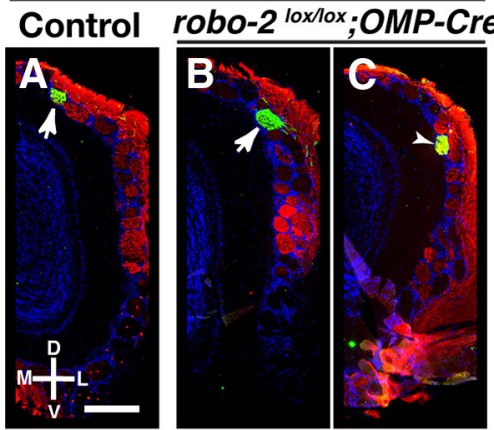

Lateral glomerulus
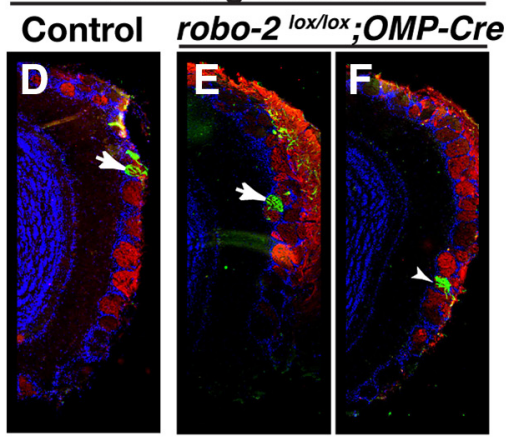

Medial glomeruli

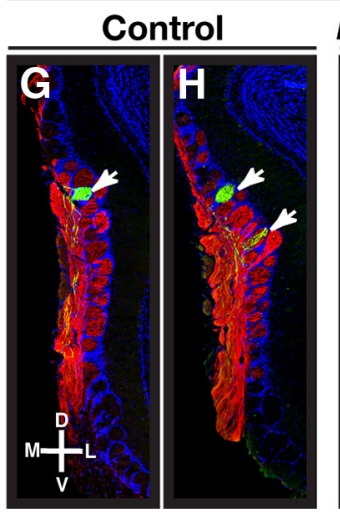

robo-2 lox/lox;OMP-Cre

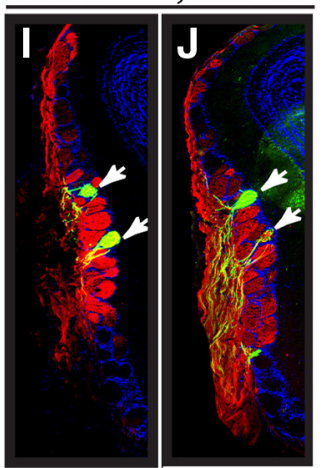

Figure 3. Robo-2 is required for the targeting of MOR174-9-expressing OSN axons in the OB. $A-J$, Coronal sections of OBs isolated from control $(\boldsymbol{A}, \boldsymbol{D}, \boldsymbol{G}, \boldsymbol{H})$ and robo-2 ${ }^{\text {lox/lox }} ;$ OMP-Cre; MOR174-9-tau-GFP $(\boldsymbol{B}, \boldsymbol{C}, \boldsymbol{E}, \boldsymbol{F}, \boldsymbol{I}, \boldsymbol{J})$ mice stained with NQ0-1 and GFP antibodies $(\boldsymbol{A}-\boldsymbol{J})$. NQO-1 antibodies stain axons of OSNs innervating the dorsal region of the $O B$. On the lateral side of the $O B$, a GFP-positive glomerulus is consistently observed in the dorsal region of the $O B(A-C)$ and a second GFP-positive glomerulus is observed in approximately half of the OBs analyzed (14/28 controls and 18/25 robo-2 $2^{\text {lox/lox }} ;$ OMP-Cre $)(\boldsymbol{D}-\boldsymbol{F})$. In addition, a third glomerulus was observed more ventrally in two OBs from control mice and in six OBs from robo-2 ${ }^{\text {lox/lox; }}$ OMP-Cre mice (shown in yellow on the scatter plot in $\boldsymbol{K}$ ). On the medial side of the $\mathrm{OB}$, all OBs analyzed contained at least one GFP-positive glomerulus ( $\boldsymbol{G}$, $\boldsymbol{H}$ ) and the majority of OBs analyzed (19/27 for controls and 19/25 for robo-2 ${ }^{\text {lox/lox}}$; OMP-Cre mice) contained two GFP-positive glomeruli $(\boldsymbol{H}, \boldsymbol{J})$. Furthermore, a few OBs analyzed contained an additional GFP-positive glomerulus (2/28 controls and 6/27 robo- $2^{\text {lox/lox }} ; O M P$ - $(r e) . K, L$, The relative positions of GFP-positive glomeruli in the dorsoventral axis of the $O B$ on the lateral and medial sides of the $O B$ were assessed and represented on scatter plots $(\boldsymbol{K}, \boldsymbol{L})$. Parameters are shown as mean \pm SEM. The mean location of glomeruli innervated by MOR174-9-expressing axons on both the lateral and medial sides of the OB is shifted ventrally in robo- $2^{\text {lox/lox }}$;OMP-Cre. Note that the additional glomeruli observed in some bulbs (represented in yellow) were not included in the calculation of the mean. Sections containing glomeruli located close to the mean angle are shown in $\boldsymbol{A}, \boldsymbol{B}, \boldsymbol{D}, \boldsymbol{E}, \boldsymbol{G}-\boldsymbol{J}$. In $\boldsymbol{C}$ and $\boldsymbol{F}$, sections with a more severe ventral shift in the location of the glomeruli are shown. ${ }^{* * *} p<0.001 .{ }^{* *} p<0.01$. D, Dorsal; V, ventral; L, lateral; M, medial. Scale bar, $250 \mu \mathrm{m}$.

mental material). Furthermore, the OBs in these mice were of a size and contained a number of glomeruli similar to OBs from control animals (data not shown). To visualize targeting of OSN axons, Robo-2;OMP-Cre mice were crossed with mice that express reporter genes in MOR1-3- (tau-lacZ), S50- (tau-GFP), MOR174-9- (GFP), and M72- (tau-lacZ) expressing OSNs.
Examining whole-mount preparations of OBs from robo-2 $2^{\text {lox/lox }}$; OMP-Cre; MOR174-9 tau-GFP, it appeared that MOR174-9 positive glomeruli are shifted ventrally in the $\mathrm{OB}$ when compared to controls (Fig. $1 J-M$ ). Furthermore, in robo-2 ${ }^{\text {lox/lox }}$; OMP-Cre; M72 tau-lacZ mice, an additional glomerulus is observed on the dorsolateral side of the OB (Fig. $1 N-\mathrm{O}^{\prime \prime}$ ) as well as on the medial side of the OB (data not shown). In contrast, the targeting of MOR1-3- and S50-expressing axons appeared unaffected in mutant mice (Fig. $1 D-I)$.

To quantify these observations, the location of MOR174-9- and MOR1-3innervated glomeruli in the OBs of control and robo- $2^{\text {lox/lox }}$; OMP-Cre mice was determined by immunostaining consecutive coronal sections of the $\mathrm{OB}$ with GFP or $\beta$-gal antibodies. In controls and robo-2 $2^{\text {lox/lox }}$; OMP-Cre; MOR174-9-GFP mice, one or two glomeruli were detected on both the medial and lateral sides of the $\mathrm{OB}$ in most mice analyzed (Fig. $3 A-J$ ). In a subset of control (1/14) and robo-2 $2^{\text {lox/lox; }}$ OMP-Cre; MOR174-9-GFP (3/12) mice, a third glomerulus was also observed on the lateral side of the OB. Examination of the location of MOR174-9 glomeruli revealed an overall dorsal to ventral shift in the distribution of both medial and lateral glomeruli in robo-2 $2^{\text {lox/lox }}$; OMP-Cre; MOR174-9-GFP mice (Fig. $3 K, L$ ). In contrast, we did not observe a significant change in the distribution of MOR1-3-positive glomeruli in the dorsal-ventral axis of the OB in robo-2 $2^{\text {lox/lox }}$; OMP-Cre; MOR1-3 taulacZ mice (Fig. 4A-E).

Our results indicate that Robo-2 is required for the coalescence of MOR1749- and M72-expressing axons in specific glomeruli but appears dispensable for the convergence of MOR1-3- and S50-expressing axons in the OB. Our data also indicate that the glomerular map within the DII region of the $\mathrm{OB}$ is disrupted in robo- $2^{\text {lox/lox}}$; OMP-Cre mice, which may lead to improper processing of odorant signals in this region of the $\mathrm{OB}$.

\section{Reduced innate avoidance behavior in robo- $2^{\text {lox/lox}}$; \\ OMP-Cre mice}

The ability of mice to detect and respond to aversive odorants has been linked to the activation of glomeruli in the dorsal region of the OB: ablation of OSNs that innervate this region resulted in a loss of innate avoidance behavior in response to the predator odorant TMT, a component of fox feces, and to the aliphatic acid $2 \mathrm{MB}$, a pungent odorant of spoiled food (Kobayakawa et al., 2007). Furthermore, specific deletion of OSNs innervating the DII region of the OB affected the innate avoidance 


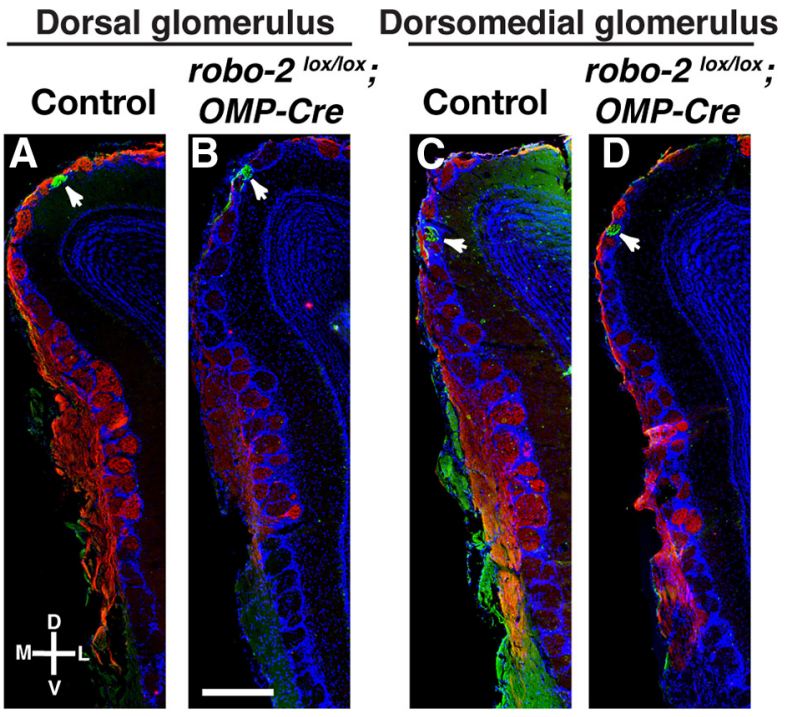

E

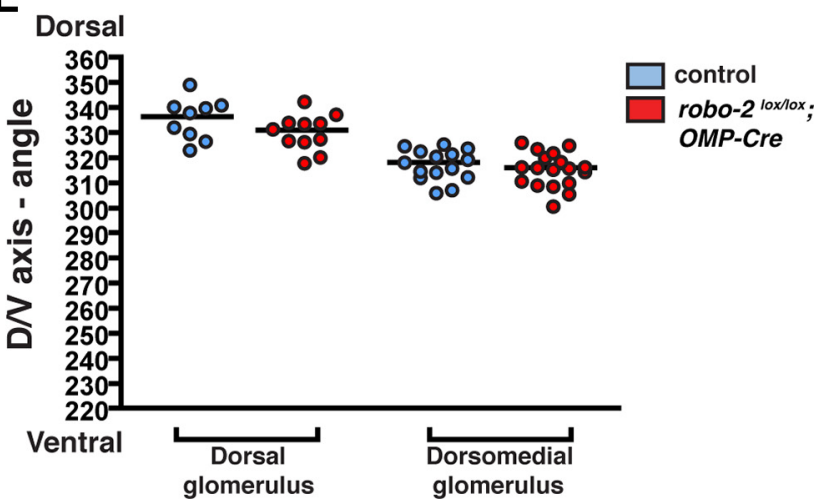

Figure 4. MOR1-3-expressing OSN axons coalesce accurately in robo-2 $2^{\text {lox/lox }}$ OMP-Cre mice. $A-D$, Coronal sections of OBs isolated from control $(A, C)$ and robo-2 $2^{\text {lox/lox }} ;$ OMP-Cre; MOR1-3tau-lacZ $(\boldsymbol{B}, \boldsymbol{D})$ mice stained with $\mathrm{NQ0}-1$ and $\beta$-galactosidase antibodies $(\boldsymbol{A}-\boldsymbol{D})$. A $\beta$-galactosidase-positive glomerulus is consistently observed in the dorsomedial part of the $O B$ in all mice analyzed $(\boldsymbol{C}, \boldsymbol{D})$. In addition, a second $\beta$-galactosidase-positive glomerulus is observed on the dorsal part of the $O B$ in approximately half of the $O B$ s analyzed ( $9 / 17$ controls and $12 / 20$ robo- $2^{\text {lox/lox }} ;$ OMP-Cre $(\boldsymbol{A}, \boldsymbol{B})$. $\boldsymbol{E}$, The relative positions of $\beta$-galactosidase-positive glomeruli in the dorsoventral axis of the $\mathrm{OB}$ was assessed and represented on a scatter plot. Parameters are shown as mean \pm SEM. No significant change was observed in the mean location of MOR1-3-positive glomeruli in robo-2 $2^{\text {lox/lox }}$; OMP-Cre mice. Note that in $\boldsymbol{A}-\boldsymbol{D}$ sections with glomeruli located approximately at the mean angle are shown. D, Dorsal; $\mathrm{V}$, ventral; $\mathrm{L}$, lateral; $\mathrm{M}$, medial. Scale bar, $500 \mu \mathrm{m}$.

behavior of mice in response to TMT but did not affect the response to $2 \mathrm{MB}$ acid, suggesting that the DII region plays a critical role in the response to TMT (Kobayakawa et al., 2007). To examine whether an accurate glomerular map in the dorsal part of the $\mathrm{OB}$ is required for the innate avoidance behavior of mice to TMT and $2 \mathrm{MB}$ acid, we performed olfactory preference and avoidance tests on the robo- $2^{\text {lox } / l o x}$; OMP-Cre mice.

For the olfactory preference test, control and mutant mice were placed in the presence of filter paper scented with specific odorants, including peanut butter, TMT, or $2 \mathrm{MB}$ acid. Control and robo-2 $2^{l o x / l o x}$; OMP-Cre mice responded equally to peanut butter, spending the same amount of time investigating this attractive odorant (Fig. 5A). In contrast, robo-2 $2^{\text {lox/lox }}$; OMP-Cre mice had reduced aversive responses to TMT, spending longer durations investigating the TMT-scented paper than control mice (Fig. 5A). Both control and robo-2 $2^{\text {lox/lox }}$; OMP-Cre mice responded similarly to the aversive odorant $2 \mathrm{MB}$ acid. These re-
A

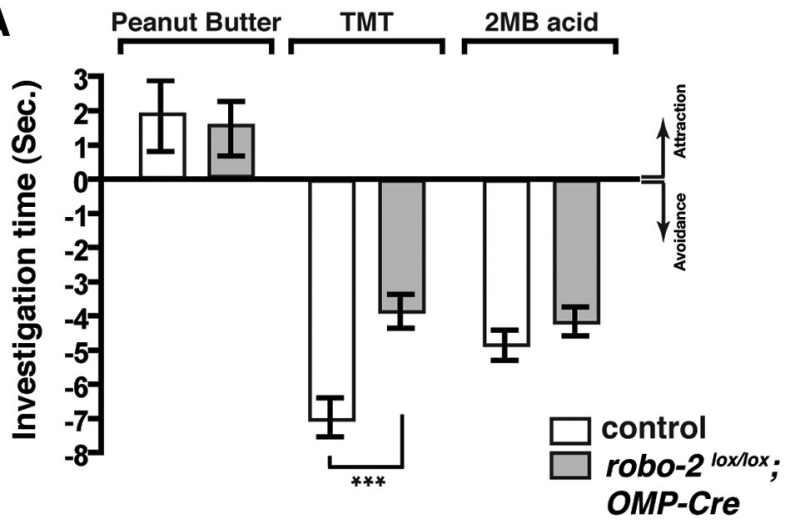

\section{B}
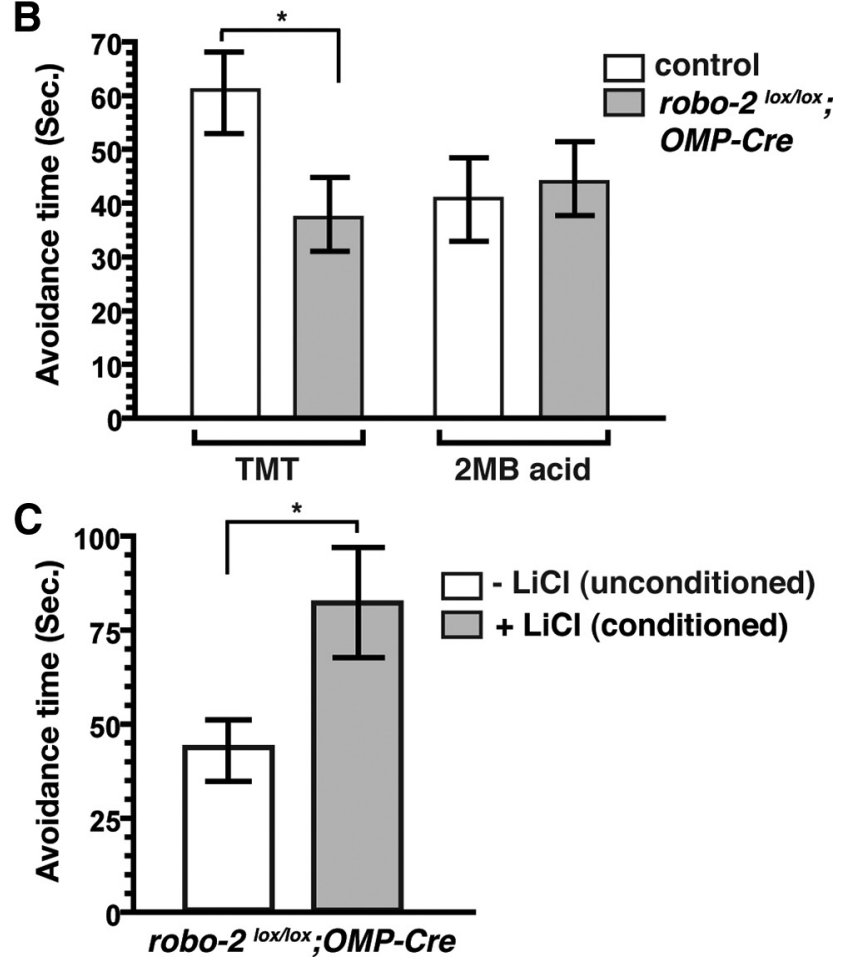

Figure 5. Reduced avoidance behavior in response to TMT in robo-2 $2^{10 x / 10 x} ;$ OMP-Cremice. $A$, Innate olfactory preference test. The duration of time spent by a mouse investigating a filter paper scented with peanut butter, TMT, or $2 M B$ acid was measured over a period of $3 \mathrm{~min}$. The mean investigative time (in seconds; \pm SEM) is shown for each odorant after subtraction of the mean investigative time

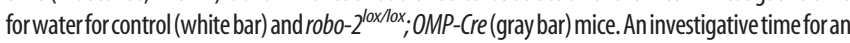
odorant that is less than for water is defined as an avoidance response. For control mice, $n=14$ for peanut butter, 18 for TMT, and 14 for $2 \mathrm{MB}$ acid. For robo-20x/lox; OMP-Cre mice, $n=14$ for peanut butter, 20 for TMT, and 14 for 2 MB acid. ${ }^{* *} p<0.001$. B. Innate olfactory avoidance tests. A test cage was subdivided into two regions (1:3) using a tape marker on the side of the cage. A scented filter paper was placed in the smaller partition and the duration of time spent by each animal in the larger partition of the cage was measured over a period of $3 \mathrm{~min}$. The mean avoidance times (in seconds; \pm SEM) for each test odorant are shown relative to the mean avoidance time for water for control (white bar) and robo-2 $2^{\text {lox/lox }}$; OMP-Cre (gray bar) mice. For TMT, $n=17$ control and 19 robo-2 $2^{\text {lox/lox }}$; OMP-Cremice. For 2MB acid, $n=12$ control and 12 robo- $2^{\text {lox/lox }}$;OMP-Cre mice. ${ }^{*} p<0.05$. See also supplemental Movie S1, available at www.jneurosci.org as supplemental material. C, Avoidance test after LiCl conditioning. robo-2 $2^{10 x / 10 x} ;$ OMP-Cre mice were aversively conditioned to TMT with a LiCl injection. Mean avoidance times (in seconds; \pm SEM) of a filter paper scented with TMT for unconditioned mice (white bar) are compared to the mean avoidance time for conditioned mice (gray bar) over the 3 min test period ( $n=11$ each for unconditioned and conditioned mice). ${ }^{*} p<0.05$.

sults therefore suggested that robo- $2^{\text {lox/lox }}$; OMP-Cre mice show a reduced responsiveness to TMT but not to $2 \mathrm{MB}$ acid.

We next assessed the innate avoidance behavior of robo- $2^{\text {lox/lox; }}$ OMP-Cre mice to TMT and $2 \mathrm{MB}$ acid. The robo-2 $2^{\text {lox } / l o x}$; OMP-Cre 
mice showed a selective decrease in avoidance behavior in response to TMT (Fig. 5B; supplemental Movie S1, available at www. jneurosci.org as supplemental material). In contrast, their avoidance response to $2 \mathrm{MB}$ acid was similar to control mice (Fig. $5 B$ ).

Our observation of reduced avoidance behavior of robo- $2^{\text {lox } / l o x}$; $O M P$-Cre mice in response to TMT suggests that responses mediated by the DII region of the $\mathrm{OB}$ are disturbed in these mice. Interestingly, responses mediated by the DI region, such as avoidance of $2 \mathrm{MB}$ acid, are unaltered in robo-2 $2^{\text {lox/lox }}$; OMP-Cre mice. In light of the defects observed in the targeting of MOR174-9 and M72 OSN axons in the DII region of the OB of robo- $2^{\text {lox } / l o x}$; OMPCre mice, it is likely that OSNs expressing other ORs, including those detecting TMT, are also mistargeted in this region. The reduced avoidance behavior to TMT observed in robo-2 $2^{\text {lox/lox }}$; OMP-Cre mice cannot be attributed to a decreased detection of TMT by OSNs since these mice can be conditioned for aversive reactions to TMT by injection of the irritant $\mathrm{LiCl}$ (Fig. $5 \mathrm{C}$ ). It is therefore likely that inaccurate glomerular mapping underlies the behavioral defects observed in robo-2 $2^{\text {lox } / l o x}$; OMP-Cre mice.

\section{Discussion}

\section{Regulation of avoidance responses to TMT}

Processing of odorant information in the dorsal region of the $\mathrm{OB}$ has been associated with the modulation of innate behaviors in response to aversive and predator odorants. Innate behavior, in contrast to associative behavior, is independent of prior experience and learning and may therefore be hard-wired during development. Here we show that the pattern of coalescence of OSN axons into glomeruli of the DII region of the OB is critical for avoidance responses to the aversive odorant TMT.

We cannot completely exclude the possibility that changes in the wiring of the accessory olfactory system (AOS) may also be a factor in the reduced avoidance response to TMT observed in robo-2 $2^{\text {lox/lox }}$; OMP-Cre mice. Indeed we have previously reported that some basal vomeronasal sensory neurons erroneously innervate the anterior region of the accessory olfactory bulb (AOB) in these mice (Prince et al., 2009). TMT exposure induces c-fos activation in target regions of $\mathrm{AOB}$ mitral cells, including the medial and basolateral amygdala (Day et al., 2004). In addition, TMT-induced responses are blocked by temporary inactivation of the medial amygdala, supporting a role for the AOS in this response (Müller and Fendt, 2006). Therefore, it remains possible that activation of these brain regions contributes to TMT avoidance responses in mice, but it is noteworthy that vomeronasal organ function is not required for this response (Papes et al., 2010).

The dorsal region of the $\mathrm{OB}$ is critical for avoidance behavior in response to TMT, but TMT also activates glomeruli in the ventral region of the $\mathrm{OB}$ (Kobayakawa et al., 2007). It is therefore possible that, in addition to the defects observed in the DII region, changes in the glomerular map in the ventral region of the $\mathrm{OB}$ may also contribute to the reduced avoidance response observed in robo-2 $2^{l o x} / l o x ; O M P-C r e$ mice. The future examination of connectivity in the ventral OB of robo-2 $2^{l o x / l o x}$; OMP-Cre mice as well as the generation of genetically modified mice bearing a selective disruption of the glomerular map in the ventral OB will help address the role of this region in avoidance responses to TMT.

Robo- 2 in the wiring of the dorsal region of the olfactory bulb The formation of the glomerular map in the DII region of the OB is regulated in part by the axon guidance receptor Npn-1, which controls the anterior-posterior targeting of OSN axons within this region (Imai et al., 2009). Our results show that Robo-2 is required for the dorsal-ventral positioning of MOR174-9innervated glomeruli as well as for the accurate coalescence of M72-expressing axons in the DII region of the OB. It is therefore likely that expression of Robo-2 and Npn-1, combined with the expression of specific ORs and cell adhesion molecules, can promote the coalescence of axons into specific glomeruli of this $\mathrm{OB}$ region. Our analyses suggest that Robo-2 is dispensable for the targeting of OSN axons in the DI region of the OB. However, we cannot exclude the possibility that residual levels of Robo-2 protein remain on these axons in robo-2 $2^{l o x} / l o x ; O M P-C r e$ mice early during development of these projections, and that this is perhaps sufficient to promote coalescence of these axons onto correct targets. We think this unlikely due to several observations. First, axons that project to the dorsal region of the OB do so before E14, but they remain in the nerve layer until the beginning of glomerulogenesis around E15 (Treloar et al., 1999, 2009; Takeuchi et al., 2010). In robo-2 $2^{\text {lox/lox }}$; OMP-Cre mice, Robo-2 expression on OSN axons is already greatly reduced at E13 and mostly absent by E14, suggesting that Robo-2 expression is ablated before the coalescence of axons into glomeruli (Fig. $2 I-K$ ). Our observation that OMP is expressed by E13 in the majority, but not all, OSNs expressing a specific receptor (MOR1-3) that innervate the DI region may explain the residual expression of Robo- 2 observed at that stage (Fig. 2Q-S). It remains formally possible that Cremediated ablation of Robo-2 in OSNs that innervate the DI region does not occur quite early enough to affect the targeting of these axons in robo-2 $2^{\text {lox/lox }}$; OMP-Cre mice. Nonetheless, the OMP-Cre-mediated robo-2 gene excision provides a unique model to study the effects of selective disruption of the DII glomerular map on responses to aversive odorants.

Overall, our results indicate that formation of a precise glomerular map is essential for innate behavioral responses in mice, and suggest that the circuits regulating these responses exhibit limited plasticity to compensate for any miswiring that may take place during development.

\section{References}

Bozza T, Vassalli A, Fuss S, Zhang JJ, Weiland B, Pacifico R, Feinstein P, Mombaerts P (2009) Mapping of class I and class II odorant receptors to glomerular domains by two distinct types of olfactory sensory neurons in the mouse. Neuron 61:220-233.

Brose K, Bland KS, Wang KH, Arnott D, Henzel W, Goodman CS, TessierLavigne M, Kidd T (1999) Slit proteins bind Robo receptors and have an evolutionarily conserved role in repulsive axon guidance. Cell 96:795-806.

Buck L, Axel R (1991) A novel multigene family may encode odorant receptors: a molecular basis for odor recognition. Cell 65:175-187.

Bunting M, Bernstein KE, Greer JM, Capecchi MR, Thomas KR (1999) Targeting genes for self-excision in the germ line. Genes Dev 13:1524-1528.

Cho JH, Lépine M, Andrews W, Parnavelas J, Cloutier JF (2007) Requirement for Slit-1 and Robo-2 in zonal segregation of olfactory sensory neuron axons in the main olfactory bulb. J Neurosci 27:9094-9104.

Cho JH, Prince JE, Cloutier JF (2009) Axon guidance events in the wiring of the mammalian olfactory system. Mol Neurobiol 39:1-9.

Day HE, Masini CV, Campeau S (2004) The pattern of brain c-fos mRNA induced by a component of fox odor, 2,5-dihydro-2,4,5-trimethylthiazoline (TMT), in rats, suggests both systemic and processive stress characteristics. Brain Res 1025:139-151.

Eggan K, Baldwin K, Tackett M, Osborne J, Gogos J, Chess A, Axel R, Jaenisch R (2004) Mice cloned from olfactory sensory neurons. Nature 428: $44-49$.

Imai T, Yamazaki T, Kobayakawa R, Kobayakawa K, Abe T, Suzuki M, Sakano H (2009) Pre-target axon sorting establishes the neural map topography. Science 325:585-590.

Ishii T, Omura M, Mombaerts P (2004) Protocols for two- and three-color 
fluorescent RNA in situ hybridization of the main and accessory olfactory epithelia in mouse. J Neurocytol 33:657-669.

Johnson BA, Leon M (2007) Chemotopic odorant coding in a mammalian olfactory system. J Comp Neurol 503:1-34.

Kobayakawa K, Kobayakawa R, Matsumoto H, Oka Y, Imai T, Ikawa M, Okabe M, Ikeda T, Itohara S, Kikusui T, Mori K, Sakano H (2007) Innate versus learned odour processing in the mouse olfactory bulb. Nature 450:503-508.

Lu W, van Eerde AM, Fan X, Quintero-Rivera F, Kulkarni S, Ferguson H, Kim HG, Fan Y, Xi Q, Li QG, Sanlaville D, Andrews W, Sundaresan V, Bi W, Yan J, Giltay JC, Wijmenga C, de Jong TP, Feather SA, Woolf AS, et al. (2007) Disruption of ROBO2 is associated with urinary tract anomalies and confers risk of vesicoureteral reflux. Am J Hum Genet 80:616-632.

Malnic B, Hirono J, Sato T, Buck LB (1999) Combinatorial receptor codes for odors. Cell 96:713-723.

Miyamichi K, Serizawa S, Kimura HM, Sakano H (2005) Continuous and overlapping expression domains of odorant receptor genes in the olfactory epithelium determine the dorsal/ventral positioning of glomeruli in the olfactory bulb. J Neurosci 25:3586-3592.

Miyamichi K, Amat F, Moussavi F, Wang C, Wickersham I, Wall NR, Taniguchi H, Tasic B, Huang ZJ, He Z, Callaway EM, Horowitz MA, Luo L (2011) Cortical representations of olfactory input by trans-synaptic tracing. Nature 472:191-196.

Mombaerts P (2006) Axonal wiring in the mouse olfactory system. Annu Rev Cell Dev Biol 22:713-737.

Mombaerts P, Wang F, Dulac C, Chao SK, Nemes A, Mendelsohn M, Edmondson J, Axel R (1996) Visualizing an olfactory sensory map. Cell $87: 675-686$.

Mori K, Takahashi YK, Igarashi KM, Yamaguchi M (2006) Maps of odorant molecular features in the mammalian olfactory bulb. Physiol Rev 86:409-433.

Müller M, Fendt M (2006) Temporary inactivation of the medial and basolateral amygdala differentially affects TMT-induced fear behavior in rats. Behav Brain Res 167:57-62.

Papes F, Logan DW, Stowers L (2010) The vomeronasal organ mediates interspecies defensive behaviors through detection of protein pheromone homologs. Cell 141:692-703.

Prince JE, Cho JH, Dumontier E, Andrews W, Cutforth T, Tessier-Lavigne M, Parnavelas J, Cloutier JF (2009) Robo-2 controls the segregation of a portion of basal vomeronasal sensory neuron axons to the posterior region of the accessory olfactory bulb. J Neurosci 29:14211-14222.

Ressler KJ, Sullivan SL, Buck LB (1994) Information coding in the olfactory system: evidence for a stereotyped and highly organized epitope map in the olfactory bulb. Cell 79:1245-1255.

Schaefer ML, Finger TE, Restrepo D (2001) Variability of position of the P2 glomerulus within a map of the mouse olfactory bulb. J Comp Neurol 436:351-362.

Serizawa S, Miyamichi K, Nakatani H, Suzuki M, Saito M, Yoshihara Y, Sakano H (2003) Negative feedback regulation ensures the one receptor-one olfactory neuron rule in mouse. Science 302:2088-2094.

Takahashi H, Yoshihara S, Nishizumi H, Tsuboi A (2010) Neuropilin-2 is required for the proper targeting of ventral glomeruli in the mouse olfactory bulb. Mol Cell Neurosci 44:233-245.

Takeuchi H, Inokuchi K, Aoki M, Suto F, Tsuboi A, Matsuda I, Suzuki M, Aiba A, Serizawa S, Yoshihara Y, Fujisawa H, Sakano H (2010) Sequential arrival and graded secretion of Sema3F by olfactory neuron axons specify map topography at the bulb. Cell 141:1056-1067.

Treloar HB, Purcell AL, Greer CA (1999) Glomerular formation in the developing rat olfactory bulb. J Comp Neurol 413:289-304.

Treloar HB, Miller AM, Ray A, Greer CA (2009) Development of the olfactory system. In: The neurobiology of olfaction (Menini A, ed), pp 131156. New York: CRC

Tsuboi A, Miyazaki T, Imai T, Sakano H (2006) Olfactory sensory neurons expressing class I odorant receptors converge their axons on an anterodorsal domain of the olfactory bulb in the mouse. Eur J Neurosci 23:1436-1444.

Tsuboi A, Takafuji Y, Itoh S, Nagata K, Tabata T, Watanabe M (2009) Response properties of trigeminal ganglion mechanosensitive neurons innervating the temporomandibular joint of the rabbit. Exp Brain Res 199:107-116.

Vassar R, Chao SK, Sitcheran R, Nuñez JM, Vosshall LB, Axel R (1994) Topographic organization of sensory projections to the olfactory bulb. Cell 79:981-991.

Zhang X, Rogers M, Tian H, Zhang X, Zou DJ, Liu J, Ma M, Shepherd GM, Firestein SJ (2004) High-throughput microarray detection of olfactory receptor gene expression in the mouse. Proc Natl Acad Sci U S A 101:14168-14173.

Zhao H, Ivic L, Otaki JM, Hashimoto M, Mikoshiba K, Firestein S (1998) Functional expression of a mammalian odorant receptor. Science 279:237-242.

Zheng C, Feinstein P, Bozza T, Rodriguez I, Mombaerts P (2000) Peripheral olfactory projections are differentially affected in mice deficient in a cyclic nucleotide-gated channel subunit. Neuron 26:81-91. 